\title{
Peran Karakteristik Personal Auditor Memoderasi Pengaruh Time Budget Presure Terhadap Perilaku Disfungsional Auditor
}

\author{
I Nyoman Wirada Sanjaya ${ }^{1}$ \\ Fakultas Ekonomi dan Bisnis \\ Universitas Udayana, Indonesia. \\ Email: wiradaasanjayaa@gmail.com
}

\author{
I Dewa Gede Dharma Suputra ${ }^{2}$ \\ Fakultas Ekonomi dan Bisnis \\ Universitas Udayana, Indonesia.
}

\begin{abstract}
ABSTRAK
Tujuan dari penelitian ini adalah menganalisis peran karakteristik personal auditor memoderasi pengaruh time budget presure terhadap perilaku disfungsional auditor pada Kantor Akuntan Publik di Provinsi Bali. Penelitian ini dilakukan pada sembilan kantor yang masih aktif sampai tahun 2018 melalui metode sampel jenuh dengan jumlah auditor sebanyak 70 orang sebagai sampel. Pengumpulan data dilakukan dengan menyebarkan kuesioner dengan 70 responden yang memenuhi kriteria pengujian melalui teknik analisis Moderating Regression Analysis (MRA). Berdasarkan hasil analisis, time budget presure memiliki pengaruh positif terhadap perilaku disfungsional auditor pada Kantor Akuntan Publik di Provinsi Bali. Karakteristik personal auditor mampu memoderasi atau memperkuat pengaruh positif time budget presure terhadap perilaku disfungsional auditor pada Kantor Akuntan Publik di Provinsi Bali.
\end{abstract}

Kata Kunci : $\quad$ Time Budget Pressure; Karakteristik Personal Auditor; Perilaku Disfungsional Auditor.

\section{The Role of Personal Auditor Characteristics Moderates the Effect of Time Budget Presure on Auditor's Dysfunctional Behavior}

\begin{abstract}
The purpose of this study is to analyze the role of the characteristics of personal auditors to moderate the effect of budget time on dysfunctional auditors at the Public Accountant Office in the Province of Bali. This research was conducted in nine offices which were still active until 2018 and 70 auditors as samples through the saturated sample method. Data collection was done by distributing questionnaires with 70 respondents that met criteria of testing through the Moderating Regression Analysis (MRA) analysis technique. Based on the results of the analysis, the time budget pressure has a positive influence on the dysfunctional behavior of auditors at the Public Accountant Office in the Province of Bali. The characteristics of personal auditors are able to moderate or strengthen the positive influence of time budget pressure on the dysfunctional behavior of auditors at the Public Accountant Office in the Province of Bali.
\end{abstract}

Keywords: Auditor's Personal Characteristics; Time Budget Presure; Auditor Dysfunctional Behavior.

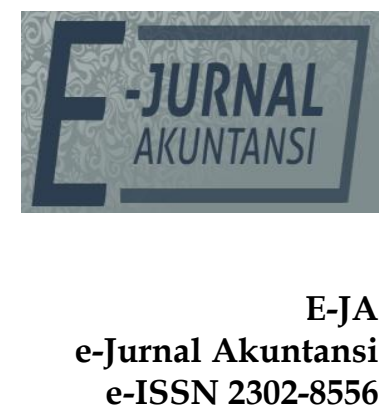

Vol. 29 No. 2

Denpasar, November

2019

Hal. 869-882

Artikel masuk: 11 September 2019

Tanggal diterima: 01 November 2019 


\section{PENDAHULUAN}

Jasa akuntan publik adalah jasa profesi yang dibutuhkan pihak eksternal perusahaan untuk menilai tanggung jawab oleh pihak manajemen atas laporan keuangan yang disajikan. Profesi ini mendapatkan kepercayaan dari masyarakat, dengan segala kompetensi yang dimiliki seorang akuntan publik diharapkan penilaian yang bebas dan tidak memihak kepada hal-hal tertentu. Dalam melakukan audit atas laporan keuangan, seorang akuntan publik tidak hanya bekerja untuk kepentingan kliennya namun juga untuk pihak luar yang memerlukan laporan audit tersebut.

Auditor yang independen sangat dibutuhkan oleh Kantor Akuntan Publik agar keputusan yang diambil dapat dipercaya dan tidak memihak serta berdasarkan fakta yang diperoleh selama proses audit (Sari dan Suryanawa, 2016). Auditing adalah serangkaian proses sistematis untuk mendapatkan dan mengevaluasi bukti-bukti sebuah informasi kemudian menilai dan melaporkan tingkat kesamaan antara informasi tersebut dengan ukuran atau kriteria yang telah ditetapkan. Seorang auditor dalam menyelesaikan laporan audit harus memiliki karakteristik personal yang terpenting dalam laporan keuangan yaitu relevan (relevance) dan dapat diandalkan (reliable)

Karakteristik personal auditor mulai menjadi sorotan semenjak terjadinya skandal keuangan yang terjadi di dunia maupun Indonesia. Beberapa kasus manipulasi yang terjadi adalah skandal pada perusahaan Global Crossing, Wordcom, dan Enron Corp yang dinyatakan wajar tanpa pengecualian oleh Kantor Akuntan Publik Arthur Enderson padahal perusahaan tersebut sedang mengalami kerugian. Kasus skandal keuangan tersebut akhirnya berdampak pada turunnya tingkat kepercayaan masyarakat, dapat dicermati bahwa kantor akuntan publik ternyata memerlukan individu-individu yang memiliki sikap etis dan professional dalam melaksanakan tugasnya sebagai auditor untuk menghindari terjadinya perilaku disfungsional auditor.

Perilaku profesional akuntan publik salah satunya diwujudkan dalam bentuk menghindari perilaku menyimpang dalam audit atau biasa disebut perilaku disfungsional auditor (Kartika, 2015). Bentuk perilaku disfungsional audit antara lain adalah prosedur audit yang dihentikan secara tiba-tiba, penggantian atau perubahan tahap audit, waktu pengerjaan yang dilaporkan auditor lebih singkat dari waktu yang sebenarnya diperlukan (Kelley dan Margheim, 1990). Ketiga perilaku tersebut cenderung mengarah pada persoalan penyimpangan sikap dan perilaku auditor dalam menghadapi berbagai tekanan, sehingga menimbulkan dampak kurangnya kepercayaan masyarakat terhadap auditor yang mengakibatkan hilangnya profesi akuntan publik secara perlahan (Dina dan Erna, 2013). Semakin banyak tugas audit yang harus dilakukan membuat setiap kantor akuntan publik harus semakin cepat dalam menyelesaikan tugas auditnya sebelum batas akhir penerbitan laporan. Kondisi tersebut menyebabkan auditor akan merasakan tekanan dengan anggaran waktu audit yang disusun dan akan memicu penerimaan perilaku disfungsional auditor (Andreas, 2016).

Perilaku disfungsional yang dilakukan auditor dapat ditimbulkan dari dalam diri sendiri seorang auditor, seperti yang dikatakan dalam theory of attitude 870 
change adalah teori yang digunakan untuk memprediksi sikap dan perilaku atas teori yang dinaunginya contohnya dissonance theories dan functional theory (Siegel dan Marconi, 1989). Dissonance theory menyatakan bahwa ketika terjadi ketidaksesuaian seseorang akan cenderung mengurangi ketidaksesuaian tersebut. Sedangkan functional theory menyatakan bahwa perubahan sikap terjadi karena adanya tuntutan dari pihak lain yang harus dipenuhi dengan melakukan apa saja untuk memenuhi tuntutan tersebut (Mahatma dan Suaryana, 2016).

Salah satu faktor yang mempengaruhi penerimaan perilaku disfungsional audit adalah karakteristik personal auditor. Karakteristik personal merupakan cerminan psikologis individu atas respon yang berupa sikap dan perilaku atas apa yang dirasakan nya. Karakteristik personal yang mempengaruhi penerimaan penyimpangan perilaku disfungsional audit diantaranya yaitu locus of control, turnover intention, dan self rate employee performance (Mahatma dan Suaryana, 2016).

Karakteristik personal auditor mempengaruhi proses pengerjaan tugas audit termasuk cara merespon tekanan terhadap pekerjaan yang dapat memicu perilaku menyimpang oleh seorang auditor. Tidak hanya tekanan terhadap pekerjaan akan tetapi perilaku yang menyimpang akan dilakukan oleh seorang auditor, terlepas dari itu adanya time budget presure dan cenderung kaku akan memotivasi auditor untuk melewati atau mengabaikan beberapa prosedur audit sehingga penugasannya dapat selesai pada waktunya tanpa memperhatikan kualitas audit (Provita, 2016). Time budget presure menjadi masalah yang cukup serius bagi auditor dalam melaksanakan tugasnya. Seorang auditor akan merasakan stress yang cukup besar saat mandapatkan tugas dengan anggaran waktu yang tidak sesuai dengan yang dibutuhkan (Dewi dan Edy, 2014). Perilaku seperti ini tentu berpengaruh terhadap perilaku disfungsional auditor (Carl, 2013).

Hasil penelitian yang dilakukan oleh Mahatma dan Suaryana (2016) menyatakan bahwa time budget pressure memoderasi pengaruh karakteristik individual auditor secara positif pada perilaku disfungsional auditor. Jenis (2016) menyatakan bahwa time budget pressure dapat memoderasi pengaruh karakteristik individual auditor terhadap perilaku disfungsional auditor. Berbeda dengan penelitian Erni (2017) dalam penelitiannya membuktikan time budget pressure tidak memperkuat pengaruh positif karakteristik individual auditor terhadap perilaku disfungsional auditor dalam melaksanakan audit perusahaan. Provita (2016) menyatakan time budget pressure tidak memperkuat pengaruh karakteristik individual auditor pada perilaku disfungsional auditor.

Melihat beberapa hasil penelitian terdahulu dan jurnal penelitian sebagai referensi dalam penelitian ini, dapat dilihat ada pengunaan beberapa variabel yang sama dengan penelitian Mahatma dan Suaryana (2016), Jenis (2016) yaitu variabel time budget pressure sebagai variabel moderasi pengaruh karakteristik individual auditor terhadap perilaku disfungsional auditor yang menyatakan memiliki pengaruh positif. Namun ada perbedaan dengan beberapa penelitian seperti yang dilakukan oleh Provita (2016) dan Erni (2017) dimana hasil yang menyatakan time budget pressure tidak memoderasi hubungan karakteristik 
individual auditor terhadap perilaku disfungsional auditor dan juga lokasi yang berbeda serta variabel lainnya sebagai variabel bebas. Sebagai perbandingan penelitian ini akan mengkaji kembali apakah time budget pressure memoderasi pengaruh karakteristik individual auditor terhadap perilaku disfungsional auditor.

Berdasarkan latar belakang masalah yang telah dipaparkan, maka dapat dirumuskan masalah dalam penelitian ini adalah sebagai berikut. Apakah time budget pressure berpengaruh terhadap perilaku disfungsional auditor di Kantor Akuntan Publik di Bali. Apakah karakteristik personal auditor memoderasi pengaruh time budget pressure terhadap perilaku disfungsional auditor di Kantor Akuntan Publik di Bali.

Hasil penelitian ini dapat memberikan gambaran dan tambahan pemahaman serta memperluas pengetahuan dan wawasan dilingkungan akademis yang berkaitan dengan penghentian prematur atas prosedur audit yang disebut dengan perilaku disfungsional auditor dan teori terkait karakteristik individual auditor dan time budget pressure. Sebagai masukan atau bahan pertimbangan bagi pihak auditor untuk meningkatkan kinerjanya dalam menjalankan tugas. Serta sebagai referensi untuk peneliti selanjutnya mengenai karakteristik individual auditor, time budget pressure dan perilaku disfungsional auditor.

Menurut Cacioppo et al., (1994) perubahan sikap (attitude change) mengacu pada cara seseorang merespon perubahan yang terjadi di lingkungan sekitarnya. Perubahan sikap yang terjadi baik menguntungkan maupun tidak tergantung pada masalah yang dihadapi. Perubahan dalam keterampilan yang terjadi karena sebuah proses pembelarajan dan perubahan sikap karena adanya sebuah pengawasan tidak termasuk dalam perubahan sikap yang dimaksud. Pengendalian diri individu serta pengendalian sosial yang tidak tergantung oleh sebuah paksaan merupakan bentuk spesifik dari perubahan sikap (attitude change).

Auditor adalah sesorang yang memiliki kompetensi tertentu dan terkualifikasi untuk melakukan prosedur audit atas laporan keuangan sebuah perusahaan maupun organisasi. Terdapat tiga jenis auditor, yang pertama adalah auditor pemerintah yang bertugas untuk melakukan audit atas keuangan negara pada instansi-instansi pemerintah. Yang kedua adalah eksternal auditor seorang praktisi dengan gelar professional dan telah mendapat izin untuk memberikan jasa audit umum dan review atas laporan keuangan. Yang ketiga adalah internal auditor yang bekerja suatu perusahaan untuk melakukan audit dan berstatus sebagai karyawan pada perusahaan tersebut yang bertugas untuk membantu pihak manajemen di dalam perusahaan.

Perilaku disfungsional audit merupakan bentuk reaksi seseorang terhadap lingkungan yang berkaitan dengan sistem pengendalian. Sistem pengendalian yang berlebihan akan memicu konflik sehingga auditor cenderung untuk berperilaku disfungsional. Jika sikap auditor menunjukkan penerimaan perilaku disfungsional maka hal tersebut menunjukkan bahwa auditor telah melakukan tindakan disungsional (David et al., 2014). 
Time budget pressure adalah suatau keadaaan ketika auditor dituntut untuk melakukan efesiensi terhadap waktu yang telah dianggarkan (Mahatma dan Suaryana, 2016). Anggaran waktu disusun untuk memprediksi lamanya waktu yang diperlukan dalam setiap tahap proses pengauditan sesuai dengan tingkat kemampuan auditor. Berdasarkan hal tersebut maka dapat disimpulkan bahwa time budget pressure merupakan bentuk anggaran waktu yang dapat memberikan tekanan terhadap seorang auditor dalam melaksanakan tugas pengauditannya yang mempengaruhi lamanya proses audit dan mengakibatkan terganggunya program kerja audit.

Karakteristik personal merupakan cerminan psikologis individu atas respon yang berupa sikap dan perilaku atas apa yang dirasakan nya. Karakteristik personal mencakup hal yang sangat luas dan merupakan faktor inter personal yang mempengaruhi perilaku individu itu sendiri dan membedakannya dengan orang lain dilihat dari cara pandangnya terhadap sebuah objek, menanggapi sesuatu serta evaluasi terhadap lingkungan sekitar yang berupa penilaian tersendiri atas kejadian sekitar lingkungannya.

Theory of attitude change adalah teori yang digunakan untuk memprediksi sikap dan perilaku atas teori yang dinaunginya contohnya dissonance theories dan functional theory (Siegel dan Marconi, 1989). Dissonance theory menyatakan bahwa ketika terjadi ketidaksesuaian seseorang akan cenderung mengurangi ketidaksesuaian tersebut. Ketika auditor mendapatkan ketidaksesuaian dalam proses pengauditan, auditor akan cenderung mengurangi bukti-bukti audit terkait sehingga ketidaksesuaian tersebut dapat berkurang. Sedangkan teori fungsional dari perubahan sikap adalah seorang auditor dapat melakukan segala macam tindakan termasuk perilaku disfungsional auditor untuk memenuhi kebutuhan akan kesesuaian tekanan atau time budget pressure yang diperolehnya (Mahatma dan Suaryana, 2016).

Beberapa penelitian seperti Annisa (2012) dalam penelitiannya membuktikan time budget pressure memiliki pengaruh signifikan terhadap perilaku disfungsional auditor dalam melaksanakan audit perusahaan. Mahatma dan Suaryana (2016) menyatakan bahwa time budget pressure secara positif berpengaruh pada perilaku disfungsional auditor. Erni (2017) dan Jenis (2016) menyatakan hal yang sama dimana time budget pressure berpengaruh positif terhadap perilaku disfungsional auditor. Berdasarkan penjelasan tersebut maka rumusan hipotesisnya adalah :

$\mathrm{H}_{1}$ : Time budget pressure berpengaruh positif pada perilaku disfungsional auditor.

Teori perubahan sikap menyarankan auditor untuk menggunakan kompetensinya dalam merencanakan progam audit dan menjalankan tahapantahapan dari setiap proses audit dengan baik. Auditor harus menggunakan keahlian profesinya dengan cermat dalam perencanaan program kerja audit, pengevaluasian bukti, serta pelaksanaan yang sesuai dengan prosedur yang telah ditetapkan untuk menghindari terjadinya perilaku disfungsional auditor.

Beberapa penelitian seperti penelitian Mahatma dan Suaryana (2016) menyatakan hal yang sama dimana karakteristik personal auditor memoderasi pengaruh time budget pressure auditor secara positif pada perilaku disfungsional auditor. Jenis (2016) dalam penelitiannya membuktikan karakteristik personal 
auditor memoderasi pengaruh positif time budget pressure terhadap perilaku disfungsional auditor dalam melaksanakan audit perusahaan. Annisa (2012), Provita (2016), dan Erni (2017) menyatakan hal yang sama bahwa karakteristik personal auditor memoderasi pengaruh time budget pressure terhadap perilaku disfungsional auditor. Berdasarkan penjelasan tersebut maka rumusan hipotesisnya adalah :

$\mathrm{H}_{2}$ : Karakteristik personal memoderasi pengaruh time budget pressure terhadap perilaku disfungsional auditor.

\section{METODE PENELITIAN}

Penelitian ini menggunakan data kualitatif yaitu nama kantor akuntan publik yang terdaftar pada directory kantor akuntan publik provinsi Bali, gambaran umum kantor akuntan publik serta struktur organisasi kantor akuntan publik. Data kuantitatif dalam penelitian yaitu jumlah auditor yang bekerja pada akuntan publik dan hasil kuesioner yang berupa jawaban responden diukur menggunakan skala Likert. Akuntan Publik di provinsi Bali berjumlah 70 orang dengan jumlah sampel yang terlibat dalam penelitian ini yaitu sebanyak 70 responden yang merupakan keseluruhan auditor yang bekerja di Kantor Akuntan Publik di provinsi Bali. Peneliti menggunakan metode sensus yaitu teknik penentuan sampel dengan menggunakan semua anggota populasi sebagai sampel (Sugiyono, 2017:68). Penelitian ini dilakukan pada 9 Kantor Akuntan Publik yang terdapat di Bali dan terdaftar pada Institut Akuntan Publik Indonesia pada tahun 2017.

Objek penelitian dalam penelitian ini adalah karakteristik personal auditor, time budget pressure dan perilaku disfungsional auditor. Data primer dalam penelitian ini adalah jawaban responden atas pertanyaan yang terdapat dalam kuesioner dan berkaitan dengan penelitian. Data sekunder dalam penelitian ini adalah data yang dikumpulkan dari sumber yang sudah ada berupa daftar nama auditor serta daftar Kantor Akuntan Publik yang terdaftar di provinsi Bali.

Metode pengumpulan data yang digunakan antara lain adalah observasi yaitu pengumpulan data dengan cara mengadakan pengamatan langsung ke perusahaan terhadap obyek yang diteliti, seperti aktivitas auditor yang bekerja pada Kantor Akuntan Publik di Bali. Yang kedua adalah dengan wawancara yaitu mengumpulkan data dengan bertanya langsung kepada sejumlah auditor yang bertujuan untuk memperoleh data berupa jumlah auditor yang bekerja pada Kantor Akuntan Publik di Bali. Yang ketiga adalah teknik kuesioner yaitu mengumpulkan data dengan cara memberikan lembaran berisikan pertanyaan atau pernyataan tertulis dan mengharapkan timbal balik dari responden berupa jawaban atas kuisioner yang diberikan (Sugiyono, 2017:162).

Analisis data dilakukan secara kuantitatif berlandaskan teori-teori yang berkaitan dengan penelitian dan menggunakan data primer yang kemudian diolah sehingga dapat diperoleh kesimpulan yang mengandung nilai-nilai ilmiah. Teknik perhitungan dan analisis data yang digunakan dalam penelitian ini adalah Moderating Regression Analysis (MRA). Moderating Regression Analysis atau teknik analisis regresi moderasi dinyatakan dalam bentuk regresi berganda 874 
dengan persamaan mirip regresi polynomial yang menggambarkan pengaruh nonlinier (Ghozali, 2016:47). Bentuk model persamaan regresi moderasi adalah sebagai berikut.

$$
Y=\alpha+\beta 1 X+\beta 2(X M)+\varepsilon
$$

Keterangan:

$\mathrm{Y} \quad=$ perilaku disfungsional auditor

a $\quad=$ konstanta

$\beta 1, \beta 2=$ koefisien regresi variabel penelitian

$\mathrm{X} \quad=$ karakteristik personal auditor

$\mathrm{M} \quad=$ time budget presure

$\varepsilon \quad=$ error term yaitu faktor kesalahan dalam penelitian

Selanjutnya diakukan uji asumsi klasik seperti uji normalitas, uji heterokedastisitas, dan uji multikolinearitas.

\section{HASIL DAN PEMBAHASAN}

Penelitian ini dilakukan untuk mengetahui peran karakteristik personal auditor memoderasi pengaruh time budget presure terhadap perilaku disfungsional auditor pada Kantor Akuntan Publik Di Provinsi Bali. Pengumpulan data dilakukan dengan menyebar kuesioner ke sembilan kantor Akuntan Publik di Bali yang disajikan pada Tabel 1.

Tabel 1. Rincian Pengiriman dan Pengembalian Kuesioner

\begin{tabular}{lcc}
\hline Kuesioner & Jumlah & Persentase \\
\hline Kuesioner yang disebar & 70 & $100 \%$ \\
Kuesioner yang tidak kembali & 0 & $0 \%$ \\
Kuesioner yang kembali & 70 & $100 \%$ \\
Kuesioner yang digunakan & 70 & $100 \%$ \\
Tingkat pengembalian kuisioner & $70 / 70 \times$ & $100 \%$ \\
\hline
\end{tabular}

Sumber: Data Penelitian, 2018

Tabel 1. menunjukan kuesioner yang disebar sebanyak 70 kuesioner kepada responden kembali dengan jumlah yang sama yaitu 70 kuisioner, sehingga tidak ada kuisioner yang tidak dikembalikan. Semua kuesioner yang disebar kembali dengan lengkap, terisi dan memenuhi kriteria, kemudian dianalisis.

Tabel 2. Karakteristik Responden Berdasarkan Jenis Kelamin

\begin{tabular}{ccc}
\hline Jenis Kelamin & Jumlah (Orang) & Persentase (\%) \\
\hline Laki-Laki & 52 & 74,3 \\
Perempuan & 18 & 25,7 \\
Total & 70 & 100 \\
\hline
\end{tabular}

Sumber: Data Penelitian, 2018.

Tabel 2. menunjukkan proporsi auditor laki-laki sebanyak 52 orang responden yaitu sebesar 74,3 persen dan auditor perempuan sebanyak 18 orang responden yaitu sebesar 25,7 persen. Hal ini menunjukkan bahwa responden pada Kantor KAP didominasi oleh auditor laki-laki. 
Tabel 3. Karakteristik Responden Berdasarkan Pendidikan Terakhir

\begin{tabular}{ccc}
\hline Pendidikan Terakhir & Jumlah (Orang) & Persentase (\%) \\
\hline Diploma 3 & 5 & 7,1 \\
S1 & 54 & 77,2 \\
S2 & 11 & 15,7 \\
Total & 70 & 100 \\
\hline
\end{tabular}

Sumber: Data Penelitian, 2018.

Tabel 3 menunjukkan data responden yang memiliki tingkat pendidikan diploma sebanyak 5 orang atau sebesar 7,1 persen, S1 sebanyak 54 orang atau sebesar 77,2 persen dan S2 sebanyak 11 orang atau sebesar 15,7 persen. Ini menandakan rata-rata tingkat pendidikan auditor adalah S.1, yang memiliki arti semakin baik tingkat pendidikan seorang auditor mampu menunjukkan tingkat kinerja yang tinggi dengan kualitas hasil audit yang lebih baik.

Tabel 4. Karakteristik Responden Berdasarkan Lama Bekerja

\begin{tabular}{ccc}
\hline Lama Bergabung Sebagai Tim Audit & Jumlah (Orang) & Persentase (\%) \\
\hline Kurang dari 5 tahun & 27 & 38,6 \\
$>5$ s/d 10 tahun & 43 & 61,4 \\
Total & 70 & 100 \\
\hline
\end{tabular}

Sumber: Data Penelitian, 2018

Tabel 4. menunjukkan lama seorang auditor bekerja sama dalam suatu tim audit pada Kantor KAP. Responden yang berada dalam tim kurang dari lima tahun adalah 27 orang atau 38,6 persen. Responden yang berada dalam tim audit lebih dari lima tahun adalah 43 orang 61,4 persen. Dapat disimpulkan bahwa secara keseluruhan responden dalam penelitian ini pernah turut serta bekerja sama dalam tim audit pada Kantor KAP sehingga responden dalam penelitian ini layak untuk digunakan.

Tabel 5. Hasil Uji Validitas dan Reabilitas

\begin{tabular}{cccccc}
\hline Variabel & $\begin{array}{c}\text { Kode } \\
\text { Instrumen }\end{array}$ & $\begin{array}{c}\text { Pearson } \\
\text { Correlation }\end{array}$ & $\begin{array}{c}\text { Ketera } \\
\text { Ngan }\end{array}$ & $\begin{array}{c}\text { Cronbach's } \\
\text { Alpha }\end{array}$ & $\begin{array}{c}\text { Ketera } \\
\text { Ngan }\end{array}$ \\
\hline Time Budget & $\mathrm{X}_{.1}$ & 0,706 & Valid & & \\
Presure $(\mathrm{X})$ & $\mathrm{X}_{.2}$ & 0,843 & Valid & & \\
& $\mathrm{X}_{.3}$ & 0,730 & Valid & 0,820 & Reliabel \\
& $\mathrm{X}_{.4}$ & 0,736 & Valid & & \\
& $\mathrm{X}_{.5}$ & 0,797 & Valid & & \\
Karakteristik & $\mathrm{M}_{.1}$ & 0,685 & Valid & & \\
Personal & $\mathrm{M}_{2}$ & 0,750 & Valid & & Reliabel \\
Auditor (M) & $\mathrm{M}_{3}$ & 0,785 & Valid & 0,727 & \\
Perilaku & $\mathrm{M}_{4}$ & 0,776 & Valid & & \\
Disfungsiona & $\mathrm{Y}_{1}$ & 0,687 & Valid & & Reliabel
\end{tabular}


$\begin{array}{llll}1 \text { Auditor }(\mathrm{Y}) & \mathrm{Y}_{3} & 0,777 & \text { Valid }\end{array}$

Sumber: Data Penelitian, 2018

Tabel 5. menunjukkan seluruh indikator pernyataan dalam variabel variabel time budget pressure, karakteristik personal auditor dan perilaku disfungsional auditor memiliki nilai pearson correlation yang lebih besar dari 0,30. Hal tersebut mengindikasikan bahwa seluruh indikator telah memenuhi syarat uji validitas. Instrumen yang digunakan dalam penelitian ini adalah kualitas audit, independensi, keahlian audit, pengalaman dan besaran fee audit memiliki koefisien Cronbach's Alpha lebih besar dari 0,60 yang berarti seluruh instrumen pada penelitian ini dapat dinyatakan reliabel.

Tabel 6. Hasil Statistik Deskriptif

\begin{tabular}{lccccc}
\hline \multicolumn{1}{c}{ Variabel } & N & Min. & Max. & Mean & $\begin{array}{c}\text { Std. } \\
\text { Deviasi }\end{array}$ \\
\hline Time Budget Presure (X) & 70 & 2,6 & 5,4 & 4,55 & 0,530 \\
$\begin{array}{l}\text { Karakteristik Personal Auditor } \\
\text { (M) }\end{array}$ & 70 & 3,0 & 5,5 & 4,48 & 0,555 \\
$\begin{array}{l}\text { Perilaku Disfungsional Auditor } \\
\text { (Y) }\end{array}$ & 70 & 2,6 & 5,6 & 4,59 & 0,676 \\
$\begin{array}{l}\text { Time Budget Presure - } \\
\text { Karakteristik Personal Auditor }\end{array}$ & 70 & 8 & 29 & 20,58 & 4,009 \\
\hline
\end{tabular}

Sumber: Data Penelitian, 2018

Tabel 6. menunjukkan variabel time budget presure $(\mathrm{X})$ memiliki nilai minimum sebesar 2,6, nilai maksimum sebesar 5,4, nilai mean sebesar 4,55, dan standar deviasi sebesar 0,530. Berdasarkan hal tersebut terdapat perbedaan nilai time budget presure pada penelitian ini terhadap nilai rata-ratanya sebesar 0,530.

Variabel karakteristik personal auditor (M) memiliki nilai minimum sebesar 3,0, nilai maksimum sebesar 5,5, nilai mean sebesar 4,48, dan standar deviasi sebesar 0,555. Hal ini berarti terjadi perbedaan nilai karakteristik personal auditor pada penelitian ini terhadap nilai rata-ratanya sebesar 0,555.

Variabel perilaku disfungsional auditor $(\mathrm{Y})$ memiliki nilai minimum sebesar 2,6, nilai maksimum sebesar 5,6, mean sebesar 4,59, dan standar deviasi sebesar 0,676. Berdasarkan hal tersebut terdapat perbedaan nilai reward pada penelitian ini terhadap nilai rata-ratanya sebesar 0,676.

Variabel time budget presure-karakteristik personal auditor memiliki nilai minimum sebesar 8 , nilai maksimum sebesar 29, mean sebesar 20,58, dan standar deviasi sebesar 4,009. Berdasarkan hal tersebut terdapat perbedaan nilai time budget presure-karakteristik personal auditor pada penelitian ini terhadap nilai rata-ratanya sebesar 4,009.

Tabel 7. Hasil Uji Asumsi Klasik

\begin{tabular}{lcccc}
\hline \multirow{2}{*}{ Parameter Yang Diuji } & Uji Normalitas & $\begin{array}{c}\text { Uji } \\
\text { Heteroskedastisitas }\end{array}$ & \multicolumn{2}{c}{$\begin{array}{c}\text { Uji } \\
\text { Multikolinearitas }\end{array}$} \\
\cline { 2 - 5 } & $\begin{array}{c}\text { Asymp. Sig. } \\
\text { (2-tailed) }\end{array}$ & Sig. & Tolerance & VIF \\
\hline $\begin{array}{l}\text { Unstandarized Residual } \\
\text { Time Budget Presure }\end{array}$ & 0,596 & 0,152 & 0,479 & 2,088
\end{tabular}

$(\mathrm{X})$ 
Karakteristik

0,197

0,479

2,088

Personal Auditor(M)

Sumber: Data Penelitian, 2018

Tabel 7. menunjukkan nilai asymp.sig, yang dimiliki lebih besar dari alpha 0,05 . Hal ini berarti bahwa model regresi yang digunakan dalam penelitian ini memiliki distribusi normal. Nilai sig. masing-masing variabel karakteristik personal auditor dan time budget pressure lebih besar dari 0,05 mengartikan bahwa variabel tersebut bebas heteroskedastisitas. Nilai VIF (Varian Inflatation Factor) tidak lebih dari 10 dan mempunyai angka tolerance tidak kurang dari 0,01, maka ini berarti dalam model regresi tidak terjadi multikolinearitas.

Tabel 8. Hasil Pelaporan Analisis MRA

\begin{tabular}{|c|c|c|}
\hline Model & \multicolumn{2}{|r|}{ Nilai } \\
\hline $\mathrm{Y}$ & \multicolumn{2}{|c|}{$-5,834+1,815 X+0,358 \mid X-M$} \\
\hline Std. Error & 3,058 & 0,171 \\
\hline $\mathrm{t}$ & $-1,908$ & 2,090 \\
\hline Sig. $t$ & $0,061 \quad 0,011$ & 0,040 \\
\hline R Square & 0,455 & \\
\hline F Hitung & 18,336 & \\
\hline Signifikansi F & 0,000 & \\
\hline
\end{tabular}

Sumber : Data Penelitian, 2018

Persamaan regresi pada Tabel 8. dapat dijelaskan untuk setiap variabel hal-hal sebagai berikut:

$$
\mathrm{Y}=-5,834+1,815 \mathrm{X}+0,358|\mathrm{X}-\mathrm{M}|
$$

Tabel 8. dapat dilihat besarnya nilai konstanta yaitu $-5,834$ menunjukan bahwa apabila perubahan variabel bebas yaitu karakteristik personal auditor dan time budget presure sama dengan nol atau bersifat konstan, maka perilaku disfungsional auditor tidak mengalami penurunan. Nilai Koefisien $\beta_{1}$ sebesar 1,815 menunjukan bahwa apabila time budget pressure meningkatkan maka perilaku disfungsional auditor juga akan meningkat. Nilai Koefisien $\beta_{2}$ sebesar 0,358 menunjukan bahwa interaksi antara variabel karakterisik personal auditor dengan time budget presure bersifat positif. Hal ini berarti karakteristik personal auditor memperkuat pengaruh time budget presure terhadap perilaku disfungsional auditor.

Tabel 8. menunjukan hasil uji statistik $\mathrm{F}$ pada nilai siginifikansi sebesar 0,000 yang lebih kecil dari tingkat $a=0,05$. Hal ini berarti variabel karakteristik personal auditor dan time budget presure secara bersamaan berpengaruh signifikan terhadap perilaku disfungsional auditor. Hal ini memiliki arti bahwa model penelitian dalam penelitian ini layak untuk digunakan.

Dari tabel 8. tersebut menunjukkan hasil perhtungan dari nilai $t$ hitung variabel $\mathrm{X}$ yaitu sebesar 1,815 dengan tingkat signifikansi sebesar 0,011 lebih kecil dibandingkan dengan taraf nyata $\alpha=0,05$. Hal ini mengandung arti bahwa time budget pressure berpengaruh positif dan signifikan terhadap perilaku disfungsional auditor. Semakin besar time budget pressure yang mempengaruhi seorang auditor dalam melaksanakan audit akan menyebabkan tingginya perilaku disfungsional auditor. 
Tabel 8. menunjukkan hasil perhitungan bahwa nilai t hitung |ZM ZX |atau variabel karakteristik personal auditor dan time budget presure yaitu sebesar 2,090 dengan tingkat signifikansi sebesar 0,040 lebih kecil dibandingkan dengan taraf nyata $a=0,05$. Hal ini memiliki arti bahwa karakteristik personal auditor berperan sebagai variabel yang memoderasi hubungan antara time budget presure terhadap perilaku disfungsional auditor.

Tabel 8. yang menunjukan bahwa nilai adjusted $R$ square model 0,455 atau sebesar $45,5 \%$. Hal ini berarti bahwa sebesar $45,5 \%$ variasi atau perubahan perilaku disfungsional auditor dapat dijelaskan oleh variasi variabel dalam model tersebut yaitu karakteristik personal auditor dan time budget presure.

Berdasarkan hasil penelitian menunjukkan adanya pengaruh positif antara time budget pressure dengan perilaku disfungsional auditor mengindikasikan bahwa semakin besar time budget pressure dalam bekerja, maka akan semakin tinggi perilaku disfungsional auditor. Time budget pressure yang mempengaruhi penerimaan penyimpangan perilaku diantaranya yaitu alokasi fee dan frekuensi revisi time budget.

Hasil penelitian ini didukung oleh penelitian Annisa (2012) dalam penelitiannya membuktikan time budget pressure memiliki pengaruh signifikan terhadap perilaku disfungsional auditor dalam melaksanakan audit perusahaan. Mahatma dan Suaryana (2016) menyatakan bahwa time budget pressure secara positif berpengaruh pada perilaku disfungsional auditor. Erni (2017) dan Jenis (2016) menyatakan hal yang sama dimana time budget pressure berpengaruh positif terhadap perilaku disfungsional auditor.

Hasil penelitian ini didukung oleh penelitian Mahatma dan Suaryana (2016) yang menyebutkan bahwa karakteristik personal auditor memoderasi pengaruh time budget pressure secara positif pada perilaku disfungsional auditor. Jenis (2016) dalam penelitiannya membuktikan karakteristik personal auditor memoderasi pengaruh positif time budget pressure terhadap perilaku disfungsional auditor dalam melaksanakan audit perusahaan. Annisa (2012) menyatakan bahwa karakteristik personal auditor memperkuat pengaruh time budget pressure terhadap perilaku disfungsional auditor. (Provita, 2016) dan Erni (2017) dalam penelitiannya menyatakan bahwa karakteristik personal auditor memoderasi pengaruh time budget pressure terhadap perilaku disfungsional auditor.

\section{SIMPULAN}

Berdasarkan hasil analisis yang telah dibahas dapat simpulan antara lain. Time budget pressure berpengaruh positif dan signifikan terhadap perilaku disfungsional auditor. Hal ini berarti time budget pressure yang ketat dirasakan oleh seorang auditor akan meningkatkan perilaku disfungsional auditor. Karakteristik individual auditor memoderasi pengaruh positif time budget pressure terhadap perilaku disfungsional auditor. Hal ini berarti semakin tinggi karakteristik individual auditor mempengaruhi beratnya time budget pressure yang dirasakan seorang auditor akan meningkatkan perilaku disfungsional auditor. 
Berdasarkan hasil penelitian dan kesimpulan diatas peneliti mengharapkan agar dapat memberikan kontribusi praktis kepada manajemen KAP untuk lebih memperhatikan anggaran waktu yang diberikan kepada auditor sehingga auditor tidak tertekan dan merasakan stress ketika waktu yang diberikan tidak cukup untuk menyelesaikan tugas audit. Bagi pihak auditor diharapkan untuk memperhatikan karakteristik personal yang baik dengan tetap berperilaku professional dalam menghadapi situasi apa pun dan sebaiknya berbagi pengalaman terhadap sesama auditor untuk mendapatkan solusi dan dapat menghindari stress atas tekanan yang didapat sehingga tidak memicu terjadinya perilaku disfungsional audit. Peneliti selanjutnya dapat menambah variabel-variabel terkait seperti ethical sensitivity dan kompetensi auditor untuk meneliti pengaruhnya terhadap perilaku disfungsional audit serta dapat melekukan penelitian pada KAP di daerah yang berbeda untuk menambah refrensi hasil penelitian sejenis maupun memperluas lingkup penelitian.

\section{REFERENSI}

Annisa, F. (2012). Karakteristik Personal Auditor sebagai Anteseden Perilaku Disfungsional Auditor dan Pengaruhnya Terhadap Kualitas Hasil Audit. Jurnal Manajemen Akuntansi, 1(1), 1-12.

Adnyani, N., Anantawikrama, T. A., dan Trisna, H. (2014). Pengaruh Skeptisme professional auditor, independensi, dan pengalaman auditor terhadap tanggung jawab auditor dalam mendeteksi kecurangan dan kekeliruan laporan keuangan (Studi Kasus pada Kantor Akuntan Publik (KAP) Wilayah Bali). Jurnal Akuntansi dan Keuangan, 2(1), 1-11.

Agoes, Sukrisno. (2000). Auditing. Edisi ke-3. Jakarta: Lembaga Penerbit Fakultas Ekonomi Universitas Indonesia

Angga, Wiguna dan Suputra, D. D. (2016). Pengaruh Tindakan Supervisi, Pengalaman Kerja, Komitmen Organisasi dan Profesional terhadap Kepuasan Kerja Auditor. Jurnal Akuntansi Universitas Udayana, 16(1), 444470.

Bastian, Indra. (2001). Audit Sektor Publik. Jakarta: Visi Global Media.

David, D., Jeffrey, Q., and David, O. (2014). Attitudes Toward Dysfunctional Audit Behavior: The Effects Of Locus Of Control, Organizational Commitment, and Position. The Journal of Applied Business Research, 19(1), 95-108.

Desi, Hutaminingsih dan Armanto, Witjaksono. (2015). Pengaruh Pengalaman Kerja, Time Budget Pressure, dan Kompetensi Terhadap Kualitas Audit (Studi Empiris pada Auditor yang Berada Kantor Akuntan Publik di DKI Jakarta). Jurnal Ekonomi Informasi Akuntasi, 1(1), 1-12.

Desmond, C. Y., Yuen, P. K., Law, C. L., and JieQi, G. (2012). Dysfunctional Auditing Behaviour: Empirical Evidence on Auditors' Behaviour in Macau. International Journal of Accounting and Information Management, 4(5), 1-20.

Dewi, E., dan Edy, S. (2014). Pengaruh Role stress Terhadap Kinerja Auditor dengan Emotional Quotient sebagai variabel moderating pada Kantor Akuntan Publik di Bali. Jurnal Akuntansi Dan Bisnis, 2(1), 1-21. 
Djony, Harijanto., Umar, Nimran., Achmad, Sudiro., dan Mintarti, Rahayu. (2013). The Influence of Role Conflict and Role Ambiguity on The Employee's Performance Through Commitment and Self-Efficacy (Study on the Nurses at Public Health Service Center of Kabupaten Kediri, East Java). Journal of Business and Management (IOSR-JBM), 8(1), 98-105.

Erni, S. (2017). Pengaruh Karakteristik Personal Auditor terhadap Tingkat Penerimaan Penyimpangan Perilaku Dalam Audit. Jurnal Akuntansi Dan Investasi, 8(2), 147-166.

Ghozali, I. (2016). Aplikasi Analisis Multivariete dengan Program IBM SPSS 23 (8th ed.). Semarang: Undip.

Gregory, A. L. and Shaun, M. M. (2007). Time budget pressure in New Zealand audits. Journal Of Bussiner Riview, 4(2), 61-68.

Hunt, M. P. and Metcalf, L. (1996). Ratioand Inquiry on Society's Closed Areas In Educating the Democratic Mind (Parker, W.). New York: State University of New York Press.

Ikatan Auditor Indonesia. (2001). Standar Profesional Auditor Publik. Jakarta: Salemba Empat.

Ikatan Akuntan Publik Indonesia. (2009). "Kode Etik Profesi Akuntan Publik". Jakarta: Institut Akuntan Publik Indonesia.

lkhsan, Arfan. (2008). Akuntansi Keperilakuan Edisi 2. Jakarta: Salemba Empat.

Indri, Septiani dan Sukartha, I. M. (2017). Pengaruh Kompleksitas Audit dan Skeptisme Profesional Auditor pada Penerimaan Perilaku Disfungsional Audit di Kantor Akuntan Publik di Bali. Jurnal Akuntansi Universitas Udayana, 18(1), 471-499.

Jenis, S. (2016). Pengaruh Karakteristik Personal Auditor Terhadap Penerimaan Perilaku Disfungsional Audit (Studi Empiris Pada Auditor Pemerintah yang Bekerja di BPK Perwakilan Sumatera Bagian Selatan). Simposium Nasional Akuntansi XIX, 4(2), 1-28.

Kartika, P. (2015). Pengaruh Karakteristik Personal dan Faktor Lingkungan Terhadap Penerimaan Perilaku Disfungsional Auditor. Jurnal Ekonomi Informasi Akuntasi, 1(1), 1-25.

Kreitner dan Kinicki. (2008). Perilaku Organisasi. Jakarta: Selemba empat.

Kusnadi, I. M. G., dan Suputra, D. D. (2015). Pengaruh Profesionalisme dan Locus of Control terhadap Kinerja Auditor di Kantor Akuntan Publik Provinsi Bali. Jurnal Akuntansi Universitas Udayana, 13(1), 276-291.

Mahatma, S. D., dan Suaryana, I. G. N. A. (2016). Time Budget Pressure Memoderasi Pengaruh Karakteristik Personal Auditor terhadap Penerimaan Perilaku Disfungsional Audit. Jurnal Akuntansi Universitas Udayana, 15(3), 1994-2023.

Marisa, Fitria. (2016). Pengaruh Time Budget Pressure, Due Profesional Care dan Eika Auditor Terhadap Kualitas Audit dengan Perilaku Disfungsional Auditor sebagai mediator (Study Empiris Pada Kantor Akuntan Publik Di Pekanbaru Dan Medan). Jurnal Online Mahasiswa Fakultas Ekonomi, 3(1), 119-132. 
Pretty, S. R. (2015). Pengaruh Kompleksitas Tugas, Locus of Control, Resiko Kesalahan, Terhadap Penurunan Kualitas Audit dengan Perilaku Disfungsional Auditor sebagai variabel Intervening. Jurnal Fekom, 2(2), 115.

Provita, W. (2016). Pengaruh Karakteristik Personal Auditor Terhadap Penerimaan Perilaku Disfungsional Audit (Studi Empiris pada Auditor Pemerintah Yang bekerja di BPKP Perwakilan Jawa Tengah dan Daerah Istimewa Yogyakarta). Jurnal Akuntansi Dan Investasi, 5(2), 251-271.

Rabih, Nehme., Abdullah, A. M., and Mohammad, Jizi. (2016). Dysfunctional Behavior of External Auditors The Collision Of Time Budget anf Time Deadline Evidence From A developing Country. The Journal of Developing Areas, 50(1), 374-387.

Ratna, S. T., and Agung, P. M. (2016). Effect of Time Budget Pressure and Locus of Control of Auditor Dysfunctional Behaviors (Survey on Legislative Auditor BPKP Gorontalo Province). Journal of Education and Vocational Research, 7(1), 6-13.

Riduwan dan Sunarto. (2007). Pengantar Statistika Untuk Penelitian Pendidikan, Sosial, Ekonomi, dan Bisnis. Bandung: Alfabeta.

Robbins, S. P., and Judge, T. A. (2008). Perilaku Organisasi, Edisi Kedua belas. Jakarta: Salemba Empat.

Sari, E. R., dan Suryanawa, I. K. (2016). Pengaruh Konflik Peran, Ketidakjelasan Peran, dan Kelebihan Peran terhadap Kinerja Auditor dengan Tekanan Waktu sebagai variabel Moderasi. Jurnal Ekonomi Dan Bisnis Udayana, 15(2), 1392-1421.

Shaun M. M., and Gregory, A. L. (2008). Time budget pressure and auditor dysfunctional behaviour within an occupational stress model. International Journal of Accountancy Business and the Public Interest, 7(1), 143.

Sugiyono. (2017). Metode Penelitian Bisnis, Pendekatan Kuantitatif, Kualitatif, Kombinasi, dan RED. Yogyakarta: Alfabeta.

Sukendra, A. Y. dan Anantawikrama, T. A. (2015). Pengaruh skeptisme profesional auditor, pengalaman auditor dan keahlian audit terhadap ketepatan pemberian opini oleh auditor (Studi Empiris pada Inspektorat Kabupaten Buleleng, Kabupaten Bangli dan Kabupaten Karangasem). Jurnal Akuntansi, 3(1), 1-12.

Surtikanti, L. L. (2015). Pengaruh Profesionalisme Akuntan Publik dan Perilaku Disfungsional Akuntan Publik Terhadap Kualitas Audit (Stusi Kasus pada Kantor Akuntan Publik di Bandung). Jurnal Akuntansi, 69-80.

Suyana, U. M. (2009). Buku Ajar Aplikasi Analisis Kuantitatif. Denpasar: Fakultas Ekonomi Universitas Udayana. 